\title{
NOÇÕES DE NUMISMÁTICA IBÉRICA (III).
}

\author{
(Continuação).
}

IX

\section{OS REIS PORTUGUESES E SUAS MOEDAS.}

Dinastia de Avís

D. João I, De Boa Memória.

\section{5-1433 \\ $100^{\circ}$ Rei}

Histórico - D. João I, segundo filho de D. Pedro I e de: D. Teresa Lourenço (filho natural) .

Nasceu em Lisboa, a 12 de abril de 1357.

Foi aclamado a 6 de abril de 1385. Reinou 50 anos.

Casou com D. Filipa de Lencastre, de quem teve cinco filhos, sendo um o infante $D$. Fernando que morreu em Ceuta e cognominado o Santo; outro D. Pedro, duque de Coimbra; o infante D. Henrique; D. Duarte que depois foi rei e dois filhos naturais.

Faleceu em Lisboa a 14 de agôsto de 1433 com 75 anos. Jaz no mosteiro da Batalha, por êle mandado levantar, como monumento de sua vitória em Aljubarrota.

D. João I foi um dos maiores monarcas portuguêses, príncipe intrépido, liberal e clemente. Além do exercício das armas a que era naturalmente dado, D. João também protegeu as letras e teve. particular afeição a Vasco da Lobeira, autor do Amadis de Gaula. Como legislador publicou leis utilíssimas e mandou traduzir o código de Justiniano.

Batalha de Trancoso. Aclamado D. João, o rei de Castela invadiu a província da Beira, onde os seus soldados cometeram tô-. da a casta de roubos, mortes e sacrilégios. A cidade de Vizeu foi. posta a saque e reduzida a cinzas, sem a menor resistência. Afinal os dois exércitos avistaram-se junto de Trancoso, onde se feriu uma sangrenta batalha da qual os portuguêses sairam vitoriosos. 
Batalha de Aljubarrota. Não fôra decisiva a vitória de Trancoso e D. João precisava de uma vitória que the assegurasse para sempre a corôa e a independência do reino que as Côrtes de Coimbra the acabavam de dar. Não tardou que se the oferecesse ensêjo para êste feito. $O$ rei de Castela, tendo sabido do êxito da 'batalha de Trancoso, entrou com um grosso exército pela província da Beira, onde levou tudo a ferro e fogo; tomou Celorico, arrasou Troncoso e apossou-se de Leiria. O rei de Portugal reuniu suas tropas às de Nuno Álvares Pereira e, em 14 de agôsto de 1385, os idois exércitos se encontravam nas planícies de Aljubarrota. Aqui se feriu uma batalha famosa, em que os castelhanos muito superiores em número foram completamente derrotados.

Esta batalha, comandada em pessoa pelo rei D. João I, decidiu da sorte de Portugal e firmou no trono o mestre de Avís.

Casamento de $D$. João. O duque de Lencastre, informado dos sucessos de D. João, julgou ser o momento favorável para fazer valer os seus direitos à corôa de Castela; aprestou uma esquadra, onde embarcou as tropas que pôde congregar e velejou para Portugal. O rei e o duque fizeram uma liga contra Castela e um dos artigos do tratado estipulava o casamento do rei de Portugal com D. Filipa, filha do duque. Os dois aliados, depois de terem invadido a Espanha sem vantagem, entraram novamente em Portugal, onde o rei castelhano lhes mandou propor a paz. Uma das condiçốes foi que D. Henrique, filho do rei, casasse com D. Catarina, filha do duque. Ouvido o rei de Portugal, o duque aceitou as condições propostas e a paz foi feita. A paz em Portugal foi definitivamente assinalada em 1403. D. João cumpriu a sua palavra, casando-se com D. Filipa de Lencastre.

Conquista de Ceuta. Quase no fim de seu glorioso reinado, $D$. João resolveu ampliar para os lados da África o domínio português e a expedição a Ceuta foi resolvida. Em agôsto de 1415 o rei de Portugal, acompanhado de seus filhos, que nessa conquista muito se distinguiram, tomava aquela cidade africana, garantia de futuros empreendimentos. E na mesquita principal da nova cidade portuguêsa, os infantes $D$. Pedro e $D$. Henrique e o príncipe $D$. Duarte eram armados, por seu pai, cavaleiros.

Primeiros descobrimentos dos portuguêses. Consolidada a independência e alargada a monarquia para os lados da África, os portuguêses sob os auspícios do imortal $D$. Henrique foram em demanda de novas terras, novos céus e estranhos climas. Para isso, - magnânimo príncipe que se tinha dedicado ao estudo das ciências matemáticas, estabelecia a sua residência em Sagres, próximo ao cabo de São Vicente, para melhor as estudar e delas tirar aplica- 
ções à navegação. Foi da marinha de Sagres que sairam os primeiros navios que levaram os portuguêses a montar o Cabo Não e a descobrir o Cabo Bojador, as ilhas da Madeira e Pôrto Santo, os arquipélagos de Cabo Verde e Bissagós e os rios Gâmbia, São Domingos e Grande.

Nova nobreza. D. João, no princípio de seu reinado, viu-se rodeado apenas do povo que 0 ajudou a libertar o reino do domínio castelhano e de alguns nobres em pequeno número; assim, pois, criou uma nobreza nova e os senhores que 0 tinham auxiliado ou com as armas na mão ou com os seus conselhos, como Nuno Ālvares Pereira, João das Regras, Mem Rodrigues de Vasconcelos, Antão Vasques d'Almada, Gil da Cunha, Martim Afonso de Melo, D. Pedro de Menezes e outros, tiveram a melhor parte do reino e. vários títulos de nobreza. Dêstes, o principal coube a $D$. Nuno Álvares Pereira que teve os títulos e os condados de Ourem, de Arraiolos, de Barcelos, de Faria e de Naiva, mais tarde incorporados à Casa de Bragança.

Heráldica. D. João I reformou o escudo das armas reais, tirando da orla cinco castelos e assentando o escudo sôbre a cruz de Avís e por timbre um dragão, não só como atributo de São Jorge que era o seu grito de guerra, mas também por possuir a Ordem da Jarreteira, de que o Santo é padroeiro. A cruz de Avís figurava no escudo, por ser êle o mestre da Ordem para a qual foi nomeado com a idade de 7 anos.

Numismática. D. João I cunhou em prata e em bilhão os riais e os meios riais; em cobre os ceitis.

Não há notícia de durante o seu reinado se ter lavrado moeda de ouro em Portugal e quando mandou cunhar os primeiros riais era ainda simplesmente "defensor e regedor do reino".

Foi grande a depreciação das moedas no tempo de D. João I, quer aumentando-se-lhes a liga, quer diminuindo-se-lhes o pêso, quer subindo-se-lhes o valor; mas o povo, talvez "pressentindo a época gloriosa que Portugal ia atravessar", nunca se queixou dessa depreciação. Teixeira de Aragão conta mesmo que o povo usava os reais cunhados por $D$. João I quando era regedor e feitos das pratas pertencentes às igrejas, como uma espécie de talismãs a que atribuia certas virtudes.

Depois da aclamação de D. João I a moeda tornou-se ainda mais fraca; mas as provas do patriotismo popular foram também mais extremas e Fernão Lopes conta que os concelhos ordenaram entre si

"que se tirasse logo hum pedido para a paga do soldo, e fazer moeda, em que montasse quatro centas mil 
liuras, que eram huas cem mil dobras; e estes dinheiros se hauiam de pagar, em graves e tarbudas, e dinheiros meudos, on em prata, se algum dar quizesse, e destas moedas auiam de fazer outra nom tam boa, de guisa que sua multiplicaçam ouvesse bi auondo para soldo das gentes, e das necessarias despesas, e assi foi que por acordo de todos mandou ElRey laurar moeda de reaes de lei de hum dinheiro, que valia cada um dez soldos".

Souza Viterbo, confirmando Severim de Faria, diz que o ceitil

"foi moeda 'de cobre mandada lavrar por D. João I em memória da cidade de Ceuta e que valia a sexta parte do rial";

Teixeira de Aragão acha mais natural que os ceitis, lavrados só por D. João I nos últimos tempos do seu reinado, fôssem destinados a correr exclusivamente em Ceuta.

\section{MOEDAS DE D. JOÃO I}

$$
\begin{aligned}
& \text { Prata }\left\{\begin{array}{l}
\text { Reaes como regedor } \\
\text { Reaes lavrados depois de rei }
\end{array}\right. \\
& \text { Bilhão }\left\{\begin{array}{l}
\text { Reaes de } 10 \text { soldos } \\
\text { Reaes de } 31 / 2 \text { libras } \\
\text { Meios reaes cruzados de } 35 \text { soldos } \\
\text { Reaes de } 10 \text { reaes }
\end{array}\right.
\end{aligned}
$$

Cobre ....... Ceitil

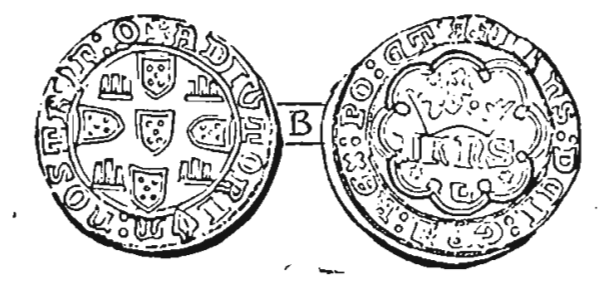

Fig. 19 - REAL - Anverso: I H N S. DEI. GRA. REX. PO. ET. A. Corồ real entre oito arcos e por baixo: J. $\Pi$. N. S. e a marca monetária $L$. Reverso: ADJUTORIUM NOSTRUM $Q$. Cinco quinas e quatro castelos Prata baixa. 


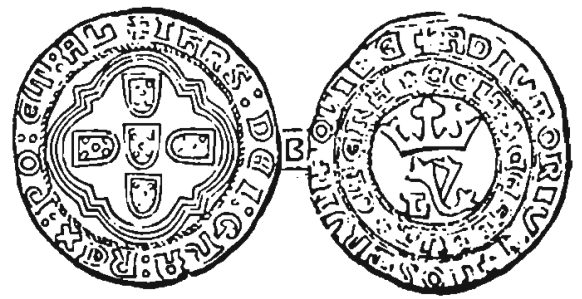

Fig. 20 - REAL - Anverso: J H N $\mathbf{s}$. DEI GRA REX PO ET AL. Quinas entre arcos.

Reverso: ADJUTORIUM NOSTRUM QUI FECIT CEELUM E TERA, em dois círculos; no campo a corôa real e por baixo as letras $Y$ e $L$.

Prata muito baixa.

Nota. Estes exemplares, embora apresentando o mesmo tipo, foram lavrados em ligas diversas.

Fraçōes dos Reaes.

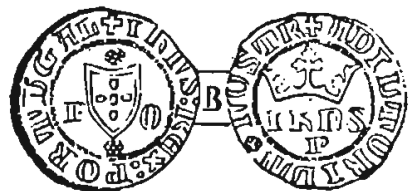

Fig. 21 - Anverso: J H N S. REX PORTUGAL. Escudo das quinas acostado de duas estrêlas e das letras $P O$.

Reverso: ADJUTORIUM NOSTR. Corôa aberta e por baixo: J. H. N. S. e a letra P. Prata baixa.

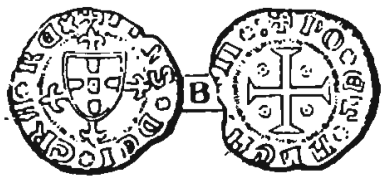

Fig. 22 - Anverso: J H N S. REI GRA REX. Escudo com as quinas e Cruz de Avís.

Reverso: PO. ET. Algarbil. Cruz da Ordem de Cristo cantonada de quatro pontos. Prata muito baixa.

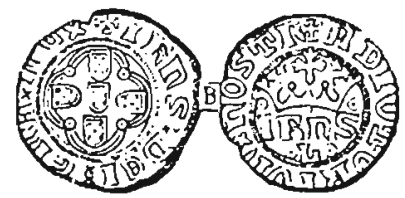

Fig. 23 - Anverso: J H N S. DEI GRA REX. Quinas entre quatro arcos.

Reverso: ADJUTORIUM NOSTR. Corôa e pontos ocultos; por baixo as iniciais $J$ H N S. e a letra monetéria L. Prata muito baixa. 


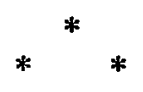

D. Duarte, $O$ Eloqüente.

\section{3-1438}

\section{$110^{\circ} \mathrm{Rei}$}

\section{Lencastre. \\ Histórico - D. Duarte, filho de D. João I e de D. Filipa de}

Nasceu em Vizeu, a 31 de outubro de 1391.

Foi aclamado em 15 de agôsto de 1433. Reinou 5 anos.

Casou a 22 de setembro de 1428 com D. Leonor de Aragão, filha de D. Fernando, rei de Aragão, da qual teve cinco filhas e quatro filhos, sendo um D. Fernando, pai do rei D. Manuel.

Faleceu em Tomar a 9 de setembro de 1438 com 46 anos. Jaz no mosteiro da Batalha.

Desde tenra idade D. Duarte deu manifestos sinais da sua capacidade para a cultura das ciências. Tão dado foi ao seu estudo, - que passava horas inteiras com os livros ou em convivência com os homens mais instruídos do seu tempo. Foi o primeiro rei português que mandou escrever as crônicas dos seus antecessores; confiando êste trabalho a Fernão Lopes, o pai da história portuguêsa .

O seu Leal Conselheiro que escreveu e dedicou à rainha, os seus escritos sôbre a Justiça e Deveres, o seu Livro de ensynança de bem cavalgar toda sela, grangearam-lhe o epíteto de Eloqüente. No ano de 1434 fêz publicar à chamada Lei mental atribuída ao célebre João das Regras, pela qual os bèns de doação régia voltariam para a corôa, quando não houvesse herdeiro direto varão. Por esta lei, as filhas eram excluídas de suceder nos bens da corôa que seus pais tivessem possuído, salvo pór especial graça do rei.

Em 1437 por instância de seus irmãos, os infantes D. Henrique e D. Fernando, desejosos de adquirir nome ilustre, empreendeu a conquista de Tânger e depois de obtida uma bula do papa Eugênio IV, em favor da cruzada contra os infiéis da África, consentiu e auxiliou os desejos dos infantes. Chegados aos campos de Tânger, como as fôrças dos árabes fôssem muito numerosas, os portuguêses foram vencidos, tendo, para abandonarem as praias africanas, de capitular, ficando o infante $D$. Fernando como refém. Esta emprêsa malograda custou grande número de vidas às fôrças de D. Duarte.

Os mouros entregavam o infante se os portuguêses : evacuassem a praça de Ceuta, a primeira conquista de Portugal em Áfri- 
ca. As côrtes de Leiria opuseram-se à troca da praça africana pelo infante e êste mesmo não o consentiu, apesar dos maus tratos que sofria e possuído de uma santa resignação, morreu cativo em Fez.

Esta decisão maguou em extremo o monarca, que amava muito a seu irmão e por certo the abreviou os dias. A peste que grassava no reino o vitimou, roubando aos portuguêses um príncipe virtuoso e muito ilustrado.

Heráldica - D. Duarte usou as mesmas armas de seu pai, sem alteração alguma.

Numismática - D. Duarte fêz cunhar em ouro os escudos; em prata os riais ou liais; em bilhão os riais brancos; em cobre os ceitis e riais pretos.

Do escudo só consta existir um exemplar numa coleção em Copenhague e Teixeira de Aragão declara não ter encontrado nos documentos coevos notícias sôbre a cunhagem desta moeda.

O monarca fêz cunhar ceitis muito semelhantes aos de seu pai e riais pretos também em cobre, com o valor computado em $31 / 2$ libras.
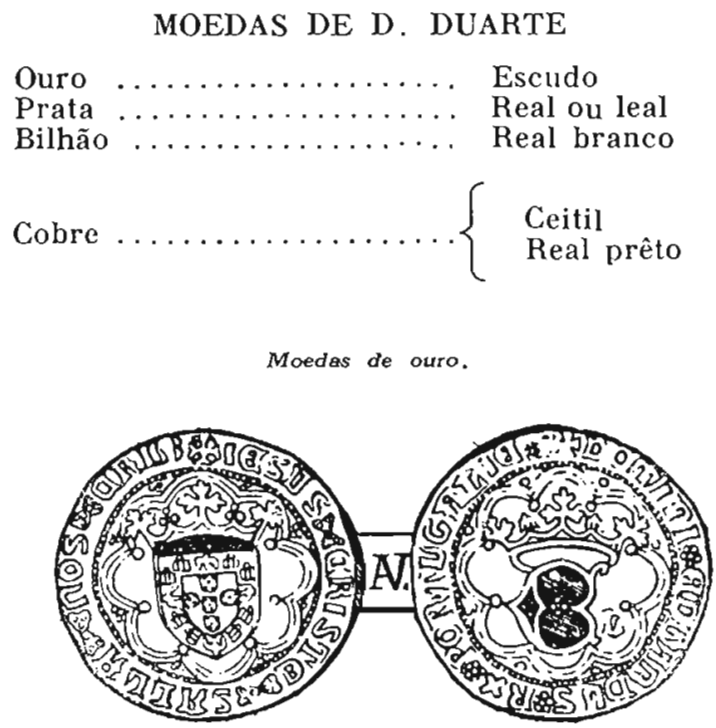

Fig. 24 - ESCUDO - Anverso: DOMINI EDUARDUS RX PORTUGalie - E coroado e a marca L

Reverso: JESUS CRISTI SALVA NOS CRUS - Escudo das armas coroado e a cruz de Avis. 


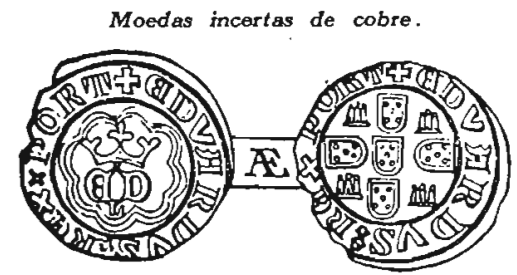

Fig. 25 - DINHEIRO - Anverso: EDUARDI REX PORT. Cinco quinas e quatro castelos.

Reverso: EDUARDI REX PORT, As iniciais E D coroadas.

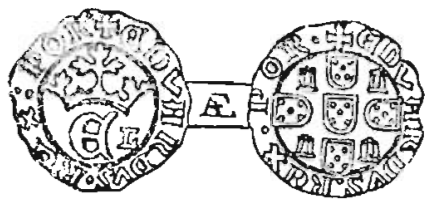

Fig. 26 - REAL PRÊTO - Anverso: EDUARDI REX PORT. No campo da moeda a inicial $E$ coroada e a letra monetáría $L$.

Reverso: EDUARDI REX PORT. Cinco quinas e quatro castelos.

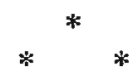

D. Afoson $V$, O Africano.

\section{8-1481}

$12 .^{\circ} \mathrm{Rei}$

Histórico - D. Afonso V, filho de D. Duarte e de D. Leonor de Aragão, nasceu em Cintra, a 15 de janeiro de 1432.

Casou com D. Isabel, filha de seu tio o infante D. Pedro, da qual teve três filhos.

Foi aclamado rei a 19 de fevereiro de 1438 , tendo 8 anos de idade e subiu ao trôno a 9 de setembro de 1448. Reinou 43 anos.

Faleceu em Cintra a 28 de agôsto de 1484, com 49 anos, vitimado pela peste. Jaz no convento da Batalha.

Conquistas em África - D. Afonso, estimulado pela malograda expedição do reinado anterior, intentou novas campanhas na África, tomando Alcácer Ceguer (1458), Arzila (1471) e Tânger, abandonada pelos mouros, assustados com as vitórias do rei de Portugal. Desde então o monarca começou a intitular-se Rei de Portugal e dos Algarves, daquém e dalém mar em África.

Para comemorar seus brilhantes feitos militares em África, D. Afonso instituiu em 1458 a Ordem Militar da Tôrre e Espada 
e a 7 de junho de 1459 fazia doação do govêrno espiritual das conquistas ultramarinas à Ordem de Cristo.

Guerra com Castela - D. Afonso depois da morte de sua espôsa $D$. Isabel, tinha ajustado o casamento com D. Joana, filha de D. Henrique de Castela. Este, falecendo, D. Fernando, rei de Aragão, casado com D. Isabel, irmã do falecido monarca, juntou aos seus títulos o de rei de Castela. D. Afonso passando a fronteira com um exército chega a Placência, casando-se com $D$. Joana, quando é reconhecido rei de Castela. Dessa cidade passa a Toro, onde se trava uma violenta batalha em que o exército por êle comandado foi vencido pelo de D. Isabel de Aragão.

Este desastre obrigou o monarca português, ferido profundamente no seu orgulho, a ir à França solicitar socôrro de Luís XI, deixando ao príncipe $\mathrm{D}$. João o govêrno do reino. $\mathrm{O}$ acolhimento que teve em Paris às suas pretensões, não foi como esperava e vendo frustradas tôdas as suas esperanças, segue para Jerusalém, escrevendo a seu filho que se fizesse proclamar rei, o que se efetuou em Santarém a 10 de novembro de 1477.

D. Afonso $V$ não tardou em abandonar o projeto que concebera em horas de amargura e voltando a Portugal foi recebido po: D. João, o qual, sendo o primeiro a prestar-lhe homenagem, faz-lhe a entrega do cetro e renuncia generosamente ao título da realeza.

Durante a estada de D. Afonso em França, a guerra continuou ras praças de Espanha que ainda seguiam o seu partido; mas tendo afinal o monarca português desistido, a 14 de setembro de 1479 o Tratado de Alcântara punha fim a luta entre Portugal e Castela.

Rui de Pina, que o conheceu pessoalmente, assim se refere:

“alto, de presença agradável, rosto redondo, barba preta; depois dos trinta anos começou a encalvecer e a engordar. Era muito religioso, humano, familiar no trato e instruido; remniu una boa livraria no paço e foi o primeiro idos nossos reis que saia freqüientes vêzes pelas praças e lugares públicos a passeio. Teve vida regrada, parco na comida, sofredor, esforçado, amigo da música, mas com dificuldade aceitava conselhos que contrariassem a sua opinião" (4) .

Heráldica - Teve o mesmo brasão de armas de seu pai e usou como divisa o rodízio de um moinho, com o dístico ja mais.

Numismática - De Afonso $\mathrm{V}$ conheceu-se em ouro o escudo, meio escudo e cruzado; em prata o rial, o rial grosso e o meio rial

(4). - Ruy de Pina, Crônica de D. Afonso V. 
grasso ou chinfram; em bilhão o rial branco, o espadim e o cotrim; em cobre o ceitil e o rial prêto.

O escudo, também conhecido pelo nome de dobra, valia 140 riais brancos. Teixeira de Aragão conta só ter conhecido dois exemplares desta moeda.

O cruzado de ouro foi, segundo Rui de Pina, mandado lavrar em 1457, quando Afonso V se preparava para a cruzada contra os turcos, que pouco antes se tinham apoderado de Constantinopla, recomendando o rei que os fizessem do mais fino ouro para serem superiores a todos os ducađos das outras nações cristãs.

O rial de prata, ou lial, foi continuado do reinado anterior; mas julga-se que Afonso V em 1457, quando mandou cunhar os cruzados, substituiu os liais pelos riais grossos, também chamados simplesmente grassos ou alfonsis.

Os meios grossas ou chinfrans foram provàvelmente cunhados pela mesma ocasião; Aragão afirma que por uma lei de 1472, o chinfram - cujo nome provinha de chifrado, adelgaçado - valia doze riais brancos.

Os riais brancos mandados lavrar por $\mathrm{D}$. Afonso $\mathrm{V}$ são a continuação dos de seu pai; Gomes Eanes de Azurara afirma que o rei mudara os riais brancos em outra moeda mais baixa chamada espadim. Severim de Faria pretende que o espadim foi criado em comemoração da Ordem da Tôrre e Espada, instituída por D. Afonso $\mathrm{V}$ para a conquista de $\mathrm{Fez}$ e refere a seguinte lenda verdadeiramente maravilhosa:

"Na mais alta tôrre desta cidade estava uma espada engastada por antigo astrólogo dos mouros, com prognóstico, que quem pelo valor das armas dali a tirasse, havia ide ser senhor do mundo".

Segundo um documento de 1482 , o cotrim valia cinco ceitis e Aragão afirma que, tendo o cotrim um pêso muito semelhante ao espadim, a sua liga devia ser muito inferior, porque valia quatro a cinco vêzes menos do que êstes. Devia ser muito inferior, mas em alguns exemplares comparados por aquêle autor, encontram-se espadins com menos prata do que os cotrins, irregularidades e abusos êstes que levavam os povos a pedirem em côrtes providências que os evitassem.

Os ceitis tornaram-se muito abundantes no tempo de D. Afonso $\mathrm{V}$; tiveram curso na metrópole pelo menos desde 1472; o seu pêso variou muitas vêzes e em vez das letras com o nome do rei, como os do tempo de D. João I e D. Duarte, tinham agora as muralhas de Ceuta "com três tôrres em cima, banhadas pelo mar". 
MOEDAS DE D. AFONSO V

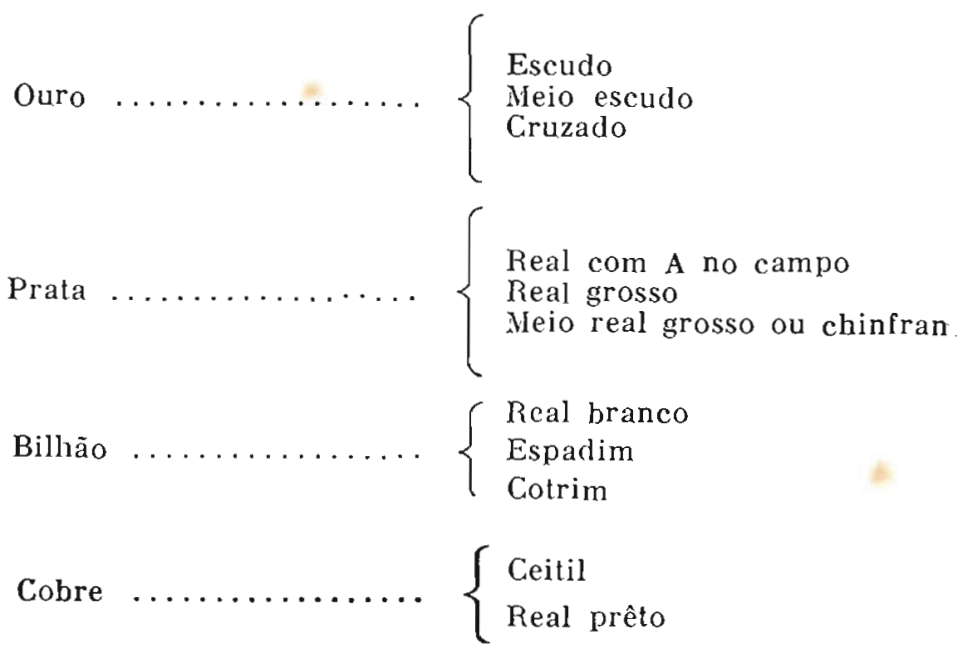

Moedas de ouro.

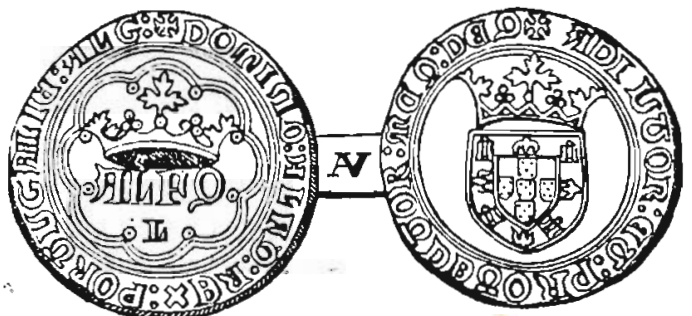

Fig. 22 - Anverso: DOMINUS ALFONSUS QUINTUS REX PORTUGALIAE ALGARBI. No campo da moeda - ALFQ - com uma corôa por cima $e$ is marca monetária L.

Reverso: ADJUTOR ET PROTECTOR MEUS DEUS. Escudo das armas com coròa e entre os castelos a cruz de Avís.

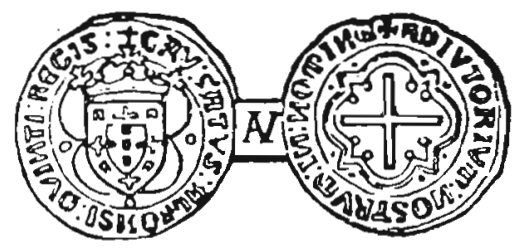

Fig. 28 - CRUZADO - Anverso: CRUSATUS ALFONSI QUINTI REGIS. Escudo , real coroado e com a cruz de Avís. Reverso: ADJUTORLUM NOSTRUM IN NOMINE. Cruz entre círculos. 


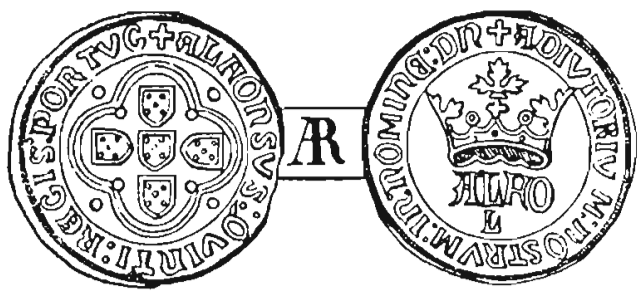

Fig. 29 - GROSSO ou ALFONSI - Anverso: ALFONSUS QUINTI REGIS PORTUGALI. No camoo da moeda - A L F Q - coroado e a marca $L$. Reverso: ADJUTORIUM NOSTRUM IN NOMINE DOMINI. Quinas entre $\operatorname{arcos}$.

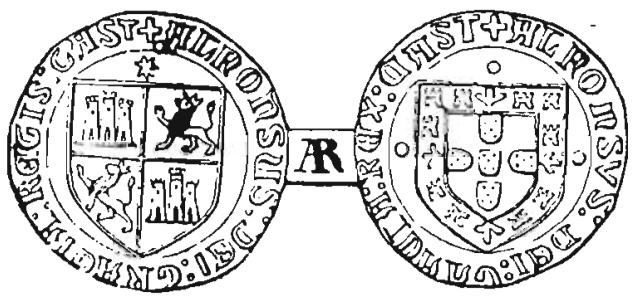

Fig. 30 - Intitulando-se D. Afonso V rei de Castela, mandou lavrar esta moeda que apresenta no anverso as armas de Portugal e no reverso as de Castela. Pela lei de 25 de dezembro de 1498, D. Joāo II mandou recolher estas e outras moedas correntes.

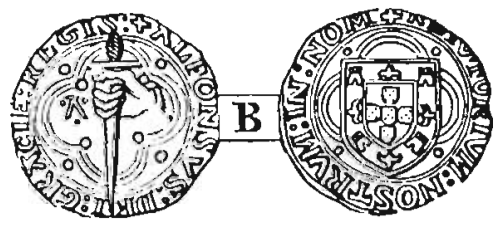

Fig 31 - ESPADIM - Anverso: ALFONSUS DEI GRATIA REgIS. Mão empu. nhando uma espada nua com a ponta para baixo. Reverso: ADJUTORIUM NOSTRUM IN NOMINE. Escudo de armas sem corôa e com a cruz de Avís.

Esta moeda "mandou lavrar EI Rei D. Afonso V em memória da Ordem da Espada que instituiu para a conquista de $F e z$, na mais alta tôrre, na qual se dizia, que estava uma espada engastada por um antigo astrólogo dos mouros, com prognóstico, que quem pelo valor das armas dali a tirasse, havia de ser senhor do mundo". 
Moedas incertas.

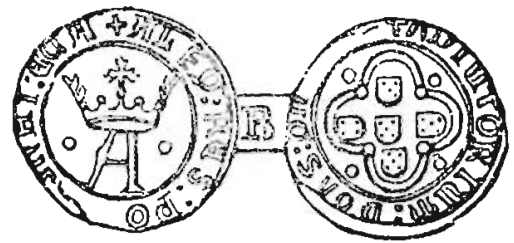

Fig. 32 - COTRIM - Prata baixa, valia 5 ceitis. No Capítulo das Côrtes Grais de D. João II, de 1481 a 1482" se queixaram os povos do damno que o Sr. D. Affonso $V$ causou no lavramento das moedas, fazendo lavrar Espadins e Cotrins, que eram já muito diminuídos em lei de moeda, arredando-os e dando lugar aos rendeiros de os desfazerem, tomando o conselho de alguns para levantar o valor das Libras, e fazendo a lei de lhes acrescentar o preço. - Respondeu a êste Capítulo o Sr. D. João II, que a Ordenação do $\mathrm{Sr}$. D. Affonso $\mathrm{V}$ se fizera com tôda a justiça, e ainda mais favorável do que o direito requeria". (Cologāo de Cốrtes da Academia, Tomo X, pág. 144).

Moedas incertas de cabre.

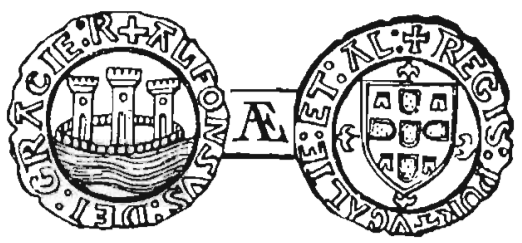

Fig. 33 - Anverso: ALFONSUS DEI GRATIA. Umas tôrres; há muitas variedades nas legendas e tipos.

Reverso: REGIS PORTUGALIE ET AL. Escudo sem corôa, com quinas, castelos e Cruz de Avís.

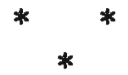

D. João II, O Príncipe Perfeito.

\section{1-1495}

$13 .^{\circ} \operatorname{Rei}$

Histórico - D. João II, filho de D. Afonso V e de D. Isabel, nasceu em Lisboa a 31 de maio de 1455 e casou em Setúbal a 22 de janeiro de 1471, com D. Leonor, filha do duque de Vizeu, D. Fernando, tendo 16 anos de idade.

Foi jurado a 25 de junho de 1455 e aclamado em Cintra a 31 de agôsto de 1481 .

Faleceu em Alvor a 25 de outubro de 1495, aos 40 anos de idade, sendo sepultado na capela de Santa Maria do Pranto, no mosteiro da Batalha. 
D. João II era de gênio belicoso e muito dado às letras, com especialidade à eloquiência e à história. Era costume seu, para saber como o seu govêrno era olhado pelos seus súditos, mandar por todo o reino pessoas de sua confiança que o informassem do modo como os seus oficiais tratavam o povo e do que nas províncias se dizia da sua pessoa e govêrno. Tinha um registro de seu uso, onde anotava as qualidades dos principais cidadãos que serviam o Estado e dos que se proponham desempenhar quaisquer cargos públicos, não admitindo a êstes senão pessoas de reconhecida capacidade: Assistia freqüentemente às decisões dos tribunais, sendo raro que o seu ânimo se inclinasse para a clemência.

No poder mostrou-se insigne na política; arcando contra os direitos senhoriais, tirou aos nobres a jurisdição criminal e outros privilégios que tornavam menos independente o poder real, empregando alguns atos que, pela dureza, deslustram a sua memória. Os fidalgos, vendo violados os direitos a que estavam acostumados, resolveram defendê-los e incumbiram dessa defesa a D. Fernando, duque de Bragança. Este foi prêso, processado em vinte e quatro horas e decapitado em Evora, tendo D. João II assistido a votação e ao lavramento da sentença. Esta morte aumentou o ódio de grande número de nobres, os quais elegeram para novo chefe o duque de Vizeu, D. Jaime, irmão da rainha e decidiram numa reunião o assassinato de D. João II.

O rei achava-se em Setúbal e sabedor do que se tramava, chamou dissimuladamente o cunhado e primo e lançando-lhe em rosto a traição, o apunhalou no vão de uma janela: Os conspiradores que não foram executados ou presos, fugiram do reino e a alguns, mesmo em país estranho, os alcançou a justiça de D. João II.

A luta encetada pelo monarca contra a nobreza teve como resultado imediato a unificação da autoridade real e a centralização da monarquia.

Passadas estas perturbações, cuidou D. João II do desenvolvimento do reino que herdara; continuando as descobertas e conquistas de Âfrica, tornou-se senhor da Guiné, da qual tomou posse Diogo de Azambuja, a 12 de dezembro de 1481. Em 1499 aparece em Lisboa Cristóvão Colombo, oferecendo-se a D. João II para continuar o descobrimento da India para o Ocidente, isto é, para descobrir as Indias ocidentais como êle lhe chamava, pois as orientais já havia até certo ponto conhecimento; mas os cosmógrafos portuguêses levaram o empreendedor monarca a repelir as propostas do ousado navegador.que se dirigindo a Espanha, ficou a serviço de Isabel de Castela. 
D. João ao morrer, deixava a grandeza do reino consolidada e aplanado o caminho para a glória, cujo fruto o seu sucessor devia colher.

Heráldica - D. João II continuou com os mesmos títulos usados por seu pai até 1485 , em que acrescentou "e Senhor de Guiné". Reformou o escudo das armas, tirou-lhe a cruz de Avís e pôs no alto os escudetes dextro e sinistro que se usavam deitados, sendo dez os castelos da orla, três em chefe, um em ponta e três de cada lado.

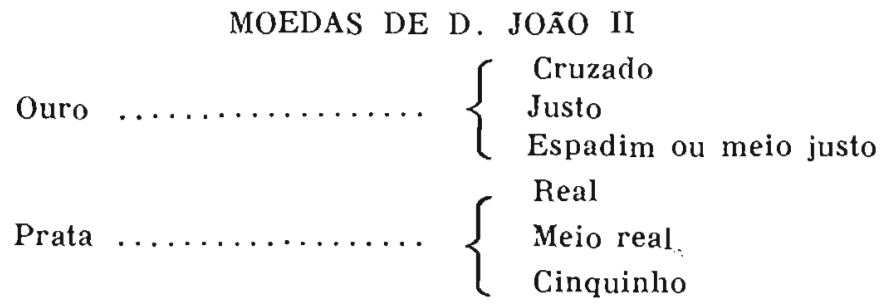

Cobre

Ceitil

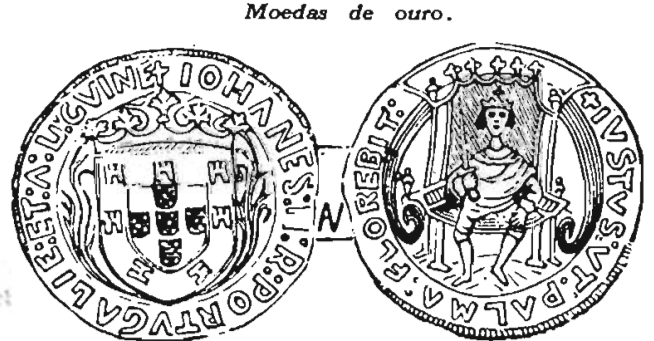

Fig. 34 - JUSTO - Anverso: JOHANES. II. R. PORTUGAliAE ET A. D. GUINE. Escudo Real com as quinas pendentes e sem a Cruz de Avís. Reverso: JUSTUS UT PALMA FLOREBIT. O rei armado e sentado no trono, tendo em uma das mãos o cetro. Há variedades nos cunhos e nas letras do nome do rei.

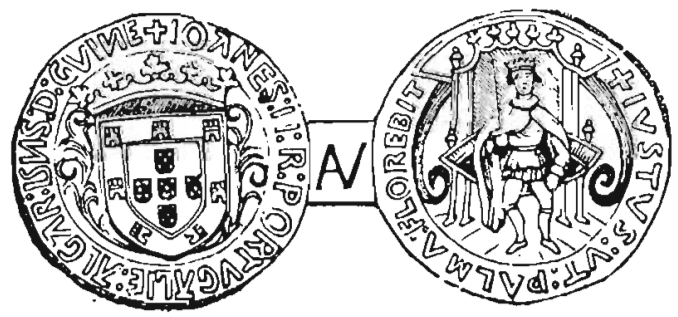

Fig. 35 - JUSTO - Variante. 


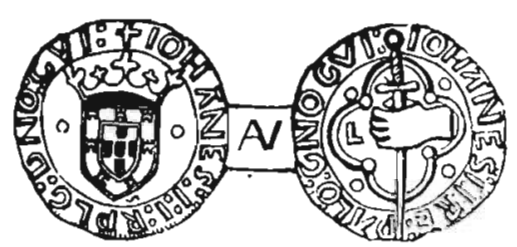

Fig. 36 - ESPADIM - Anverso: JOANNES II. REX PORT. ET ALG. Escudo das armas com as quinas pendentes.

Reverso: JOANNES II. REX PORT. ET ALG. Entre arcos, uma espada empunhada com a ponta para baixo; no campo a marca monetária $L$.

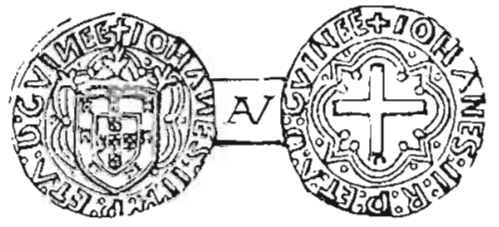

Fig. 37 - CRUZADO - Anverso: JOHANES II. R. P. ET A. D. GUINE. Escudo das armas.

Reverso: JOHANES II. R. P. T. ET A. D. GUINE. Cruz entre arcos.

Moedas de prata.

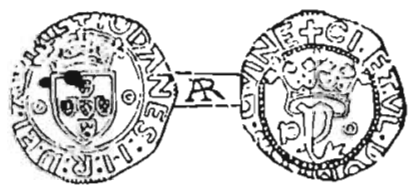

Fig. 38 - REAL DE PRATA - Anverso: JOHANES II R. P. ET AL D. G. Escudo das armas.

Reverso: JOHANES II. R. P. ET A. D. G. Outras apresentam as legendas: $C_{i}$ et ul. Daminus Guine; no certro $-\mathrm{Y}-$ coroado e as ibiciais $\mathbf{L}$ ou $\mathbf{P}$, sendo lavrados em Lisboa ou no Pôrto.

Moedas de cobre.

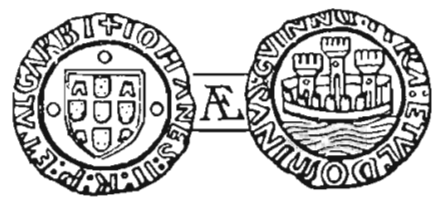

Fig. 39 - CEITIL - Anverso: JOHANES II. R. P. ET ALGARBI. Escudo com as quinas pendentes.

Reverso: JOHANES II, R P. ET ALGARBI. Umas tôrres. Algumas destas moedas trazem sòmente a seguinte legenda: Joannes Secundus.

Desde o reinado de $\mathrm{D}$. Joào II encontram-se em muitas moedas de ouro, prata e cobre, de um lado, o nome do monarca reinante e do outro o nome do rei anteriormente falecido; trata-se de um engano cometido pelos operários que as cunhavam, utilizando-se dos cunhos de dois soberanos diferentes. o mesmo êrro é encontrado nas moedas de alguns imperadores romanos. 


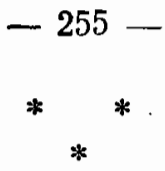

D. Manue1 I, $O$ Venturaso.

1495-1521

$14 .^{\circ}$ Rei

Histórico - D. Manue] I, último filho do infante D. Fernando e neto do rei D. Duarte, nasceu em Alconhete a 31 de maio de 1469. Subiu ao trono a 25 de outubro de 1495 , pelo falecimento, sem sucessor direto, de seu primo que o havia elevado em honras e escolhido para herdeiro do reino.

D. Manuel I casou três vêzes, sendo a primeira vez com $D$. Isabel, filha do príncipe D. Afonso; a segunda com D. Maria, filha do rei Fernando de Espanha e a terceira com D. Leonor, filha de Filipe I de Castela.

A 13 de dezembro de 1521 , atacado de febre que grassava epidêmicamente em Lisboa, ao fim de nove dias falecia nos Paços da Ribeira o rei D. Manuel I, com a idade de 52 anos e 26 de reinado.

Jaz na capela-mor da igreja de Belém.

O acaso fêz de D. Manuel um grande rei, grande pelo tempo em que viveu, pelos homens que o serviram, pelos formosos talentos que o festejaram e honraram sua côrte.

Era então a plena exuberância da raça, o ciclo de maior grandeza da nacionalidade e o rei, de inteligência modesta e alma pequenina, foi o mais afortunado de todos os reis portuguêses.

Lisboa era então uma das mais esplêndidas cidades do mundo e a côrte de D. Manuel, onde tantas preciosidades da Indias se acumulavam, a mais opulenta entre tôdas as da Europa.

Damião de Goes descreve D. Manuel

"de boa estatura, delgado, cabeça redonda, cabelo castanho, fronte descoberta, olhos esverdeados, branco de pele, voz clara, pernas compridas, assim como os braços, chegando-lhe os idedos das mãos abaixo dos joelhos. Diz também ser afável, religioso, trabalhador, amigo da música e dansas, dando repetidos saraus no Paço, com os quais folgava muito. Apresentava-se em público com grande pompa, trazendo sempre chocarreiros castelhanos (bobos) que o divertiam. Era dado à equitação, à caça e ao jôgo das canas, que atirava com muita destreza. Sabia o latim e dedicava-se ao estudo da astrologia e das crônicas de seus antepassados".

Fatos principais do reinado de $D$. Manuel $I$ - Os judeus e os mouros que não quiseram converter-se ao Cristianismo foram 
expulsos de Portugal. Os que se converteram eram conhecidos por cristãos-novos.

Em 1506 deu-se em Lisboa a matança dos cristãos-novos, por ódio de raça e de religião, tendo $\mathrm{D}$. Manuel I castigado os culpados.

Em 8 de julho de 1497 saiu do Restelo uma armada sob o comando de Vasco da Gama, para tentar o descobrimento do caminho marítimo para a Índia, o que se realizou a 20 de maio de 1498.

Em 3 de maio de 1500 Pedro Álvares Cabral descobriu o Brasil.

Em 1500 Gaspar Côrte Real descobre a Terra Nova.

Em 1502 foi fundada a cidade marroquina de Mazagão.

Depois da viagem de Vasco da Gama, os portuguêses fundam as feitorias de Cochim, Coulão e Cananor.

D. Manuel I cria o cargo de vice-rei da Índia; é nomeado em 1505, o primeira D. Francisco de Almeida. baça.

D. Francisco de Almeida conquista em 1505, Quiloa e Mom-

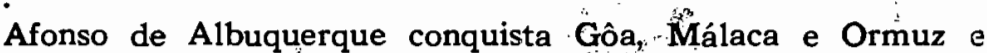
faz tributárias de Portugal tôdas as regiốes banhadas pelo Oceano Indico. Funda o Império Português do Oriente, fazendo de Gôa a capital.

D. Manuel I toma o título de Rei de Portugal e dos Algarq ves, daquém é dalém mar em África, Senhor da Guiné e da Conquista, Navegação e Comércio da Etiópia, Arábia, Pérsia e India.

Lopo Soares de.Albergaria conquista Colombo, na ilha de Ceilão.

Fernão de Magalhães faz a primeira viagem de circunavegação.

Em 1507 Diogo de Azambuja conquista Safim; em 1513 D. Jaime, duque de Bragança conquista Azamor, Tete e Almedina.

Em 1514 D. Manuel I manda uma faustosa embaixada a Ruma, chefiada por Tristão da Cunha. O Papa era então Leão X. Dessa embaixada, nos diz Damião de Góes na sua Crônica de $D$. Manuel:

"...indo com imensas riquezas, moedas" de ouro lavradas para esta ocasiāo, raras à vista pela grandeza, por ser cada uma do pêso de quinhentos escudos, de que êste presente foi estimado em um milhão de nossa moeda".

No reinado de D. Manuel I publicaram-se as Ordenanças Manuelinas. 
Construiram-se no mesmo reinado a Tôrre de Belém, as Capelas Imperfeitas do mosteiro da Batalha, o Castelo da Pena, o Convento de Cristo, em Tomar, etc.

Heráldica - D. João II havia-1he dado por emprêsa uma esfera com vários instrumentos náuticos e a legenda: Primus circumdedisti me. Nas suas edificações observa-se quase sempre êste emblema.

Usou o escudo de armas de seu antecessor, depois reduziu os castelos a sete, três em chefe e dois de cada lado.

Foi êle que estabeleceu Portugal a Heráldica e mandou pintar na sala do Paço de Cintra os brazóes de armas das famílias mais ilustres do reino.

Quando rei tomou o tratamento de Alteza.

Numismática - No tempo de D. Manuel havia em Portugal muito ouro e o rei aproveitou-o para mandar lavrar novas moedas. O numerário português circulava então por tôda a Europa e era tão apreciado na Inglaterra ou na Flandres, na França ou na Itália, que Shakespeare faz proferir à Desdemona, no Otelo, quando a gentil enamorada se queixa de ter perdido o lenço que Iago havia de aproveitar para sua intriga, a seguinte frase: "Antes queria perder a minha bôlsa cheia de cruzados!"

Teixeira de Aragão aponta como moedas do rei venturoso: em ouro, o portunguês, o cruzado e o quarto de cruzado; em prata, o meio português, o tostão, o meio tostão o índio o rial, o meio rial e o cinquinho; em cobre o rial e o ceitil.

O último exemplar cónhecido do português, adquirido e preciosamente conservado por Cenáculo, desapareceu do museu de Evora, quando os franceses saquearam a cidade em 1808; há uma cópia dessa moeda em chumbo na coleção da Biblioteca Nacional. Essa cópia tem no verso as armas reais com três anéis de cada lado, no anverso a cruz de Cristo e o carimbo IOU com uma corôa .

O português foi a maior moeda que se cunhou em Portugal até ao reinado de $\mathrm{D}$. João $\mathrm{V}$ e Gaspar Correia, nas suas Lendas da India conta que o rei Melinde gostou tanto de uma destas moedas que Vasco da Gama the mostrara, que o grande navegador the deu dez delas, pedindo-lhe que as guardasse para nunca se esquecer dos portuguêses. Vê.se por aí que essas moedas deveriam ser muito apreciadas por todos que a conheceram.

Os cruzados vêm já dos reis anteriores; julga-se que thes chamavam afonsas de ouro, por terem sido cunhados no tempo de 
Afonso V. Garcia de Rezende refere que corriam com tanta,abundância no seu tempo que,

"valendo trezentos e noventa reais, se davam para os trocarem cinco reais, mas que depois foram escasseando e que quem os precisava os comprava por quatro centos e dez reais".

O quarto de cruzado é de ouro também e diz Teixeira de Aragão ter conhecido apenas um exemplar.

O tostão ou quarto de português de prata foi criado por D Manuel, com a

"mesma divisa, escudo, letreiro dos portnguêses de ouro, de que cada qual tostão vale cinquo vintes, e cada vinte, vinte riais bräcos".

O meio tostão criado também por D. Manuel seria de 1517 e os que hoje se conhecem, são de pêso inferior ao de metade dos tostões, circunstância que Damião de Góes comenta dizendo

$$
\begin{aligned}
& \text { "quão pouquo proveitoso he ho fazer das moedas } \\
& \text { nouas...". }
\end{aligned}
$$

Os reais de prata ou vintes, tem o valor de vinte reaes brancos ou seis ceitís e são muito variados nas legendas e nas dimensões; os meios reais ou meios vintens e os cinquinhos são hoje bastante raros.

Os reais de cobre e os ceitís, muitas vêzes descontentaram o povo pela sua alteração; os primeiros tinham de um lado um $\mathbf{R}$ por baixo da corôa e do outro o escudo das armas; os segundos são a continuação dos ceitis cunhados pelos reis anteriores. Os reais valiam seis ceitiś e a propósito dêles Damião de Góes nota que correram poucos porque o preço das coisas que valiam um ceitil ou pouco mais, logo subiu a um real.

$$
\text { MOEDAS DE D. MANUEL I }
$$
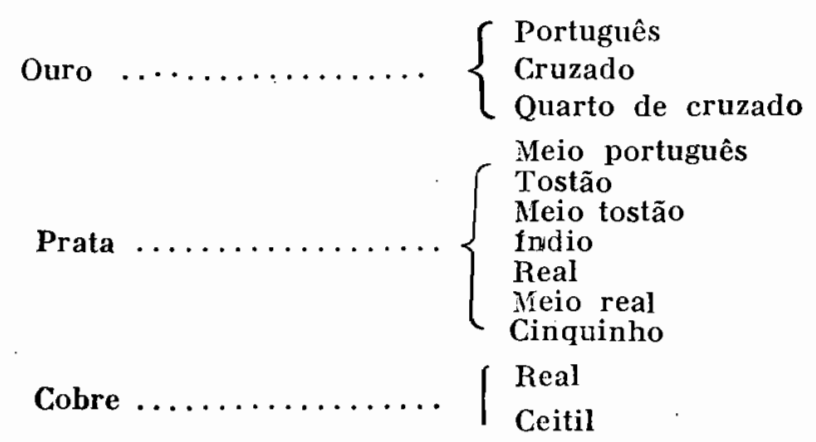
Moedas de ouro.

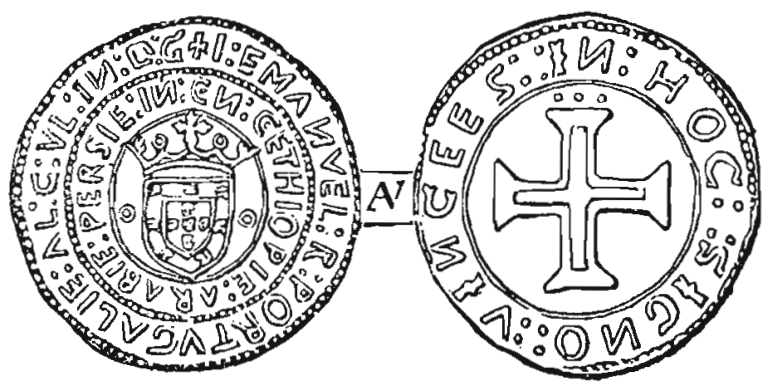

Fig. 40 - Anverso: PRIMUS EMANUEL R. PORTUGALIAE ALG. CITRA ULTRA IN AFRICA DOMINUS GUINEE, IN COMMERCII, NAVIGATIONE AETHIOPIAE, ARABIAE, PERSIAE, INDIA. Este foi o título que tomou D. Manuel I depois que Vasco da Gama descobriu o caminho maritimo para a India. Escudo das armas, tendo a legenda em dois círculos e em abreviaturas

Reverso: IN HOC SIGNO VINCES. No campo, a Cruz da Ordemi de Cristo.

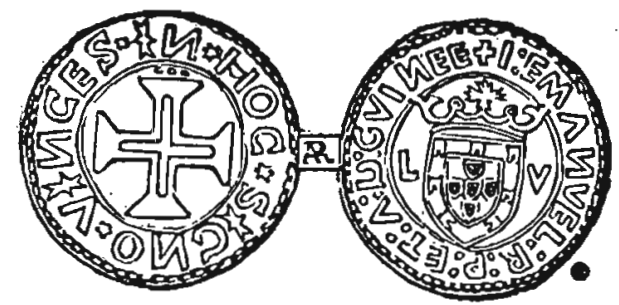

Fig. 42 - TOSTAO ou quarto de Português - Anverso: P. EMANUEL R. P. ET A. D. GUINE. Escudo das armas e aos lados os diversos sinais monetários indicativos dos Iugares onde eram cunhados: $\mathrm{L}-\mathrm{V} ; \mathrm{O}-\mathrm{V} ; \mathrm{V}-$ $\mathbf{L} ; \mathbf{P}-\mathbf{Q} ; \mathbf{L}-\mathbf{Q}$.

Reverso: IN HOC SIGNO VINCES. Cruz da Ordem de Cristo. Alguns exemplares apresentarn esta cruz cantonada de quatro estrêlas.

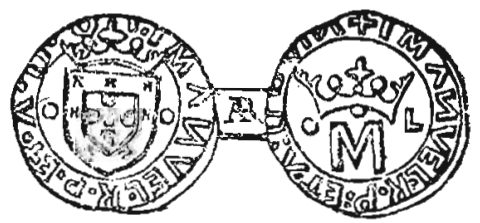

Fig. 42 - REAL DE PRATA ou VINTEM - Anverso: P. EMANUEL R. P. ET A. D. GUINE, Escudo das armas.

Reverso: P. EMANUEl R. P. ET A. D. GUINE. Corôa Real encimando a inicial $M$ do nome do monarca; ao lado a letra designando a casa monetária onde foi fabricado. 
Moedas de cobre.

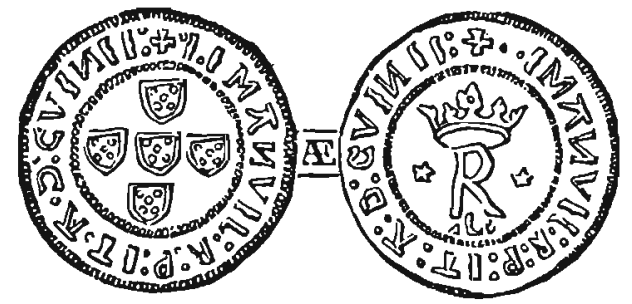

Fig. 43 - REAL DE COBRE - "Fêz-se Reaes de cobre de seis Ceptis cada Real, tinham de uma banda um - $\mathbf{R}$ - debaixo de uma corôa, e da outra o escudo das armas do reino, e de ambos os lados o letreiro - Emmantrol $\boldsymbol{R}$. Port. et A. D. Guinae - dos quais Reaes de cobre correram poucos, por preço das coisas, que valia um Ceptil, ou pouco mais, se alevantar logo no de um Real; do que se pode ver, e assim do que já disse dos Meios Tostões de prata, que El Rei fez; quão pouco proveitoso é o fazer das moedas novas, e sobretudo das grossas, principalmente nas de cobre, ou liga baixa, de que o povo se serve por meudo". (Crônica de Damiāo de Góez, Cap. 86 - Hist. Gen. Tom. IV. Tab. G, Estampa n. 50).

Nota - Estes Reaes são muito raros.

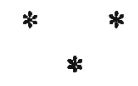

\section{João III, O Piedoso.}

\section{1-1567}

$15 .^{\circ}$ Rei

Histórico - D. João III, filho de D. Manuel I e de sua segunda mulher D. Maria, nasceu em Lisboa a 6 de junho de 1502 e se casou com D. Catarina, filha de Filipe I de Espanha, a 5 de fevereiro de 1525.

Foi aclamado a 13 de dezembro de 1522 , aos 19 anos de idade, falecendo em Lisboa a 11 de junho de 1557, com 57 anos e 35 de reinado. Jaz no mosteiro dos Jerônimos em Belém.

D. João III teria sido um monarca digno do afeto da nação, se o seu caráter tíbio, perplexo e nìmiamente religioso o não tivesse sujeitado ao jugo da superstição e do fanatismo.

Portugal estava no auge de sua glória, dominando na Ásia, na Âfrica, na América, possuindo fortalezas na India e até no Extremo Oriente, senhoreava um grande número de ilhas africanas.

Fatos notáveis dêste reinado:

D. João adquiriu, por compra à Espanha, as ilhas Molucas.

D. João III iniciou a colonização metódica do Brasil. Esste é o seu maior título de glória. 
Mandou fundar na Bahia a cidade do Salvador, capital do Brasil e divide em capitanias êste território, encarregando de sua administração a Tomé de Souza, primeiro Governador Geral do Brasil, que dela se ocupou com todo o desvêlo.

Presta auxílio ao imperador Carlos V na expedição contra Tunis, enviando uma famosa armada às ordens de seu irmão, o infante D. Luís.

Neste reinado é descoberta a grande ilha chamada depois Nova Holanda, o império do Japão e a China cede a Portugal a colônia de Macau.

D. João III abandona ao norte da África as praças de Safim, Azamor, Alcácer Ceguer e Arzila.

A Universidade é transferida para Coimbra.

D. João III obteve do papa o estabelecimento do Tribunal do Santo Ofício (Inquisição) em Portugal.

E' introduzida em Portugal a Companhia de Jesus, a quem é entregue o ensino público.

Men de Sá derrota os franceses que se haviam apoderado da região da baía da Guanabara e funda a cidade do Rio de Janeiro.

Heráldica - Teve por emprêsa a cruz de Cristo sôbre o calvário, com a legenda: in hoc signo vinces (Divisa da Inquisição).

Usou as mesmas armas de seu pai.

Numismática - D. João III continuou a usar como moedas de ouro, os portugúêses e os cruzados de seu pai e lavrou além dessas, também em ouro, os sanvicentes e os meios sanvicentes.

Os desenhos dos sanvicentes foram feitos por Antônio de Holanda e seu filho Francisco de Holanda, como êste próprio conta no seu interessante manuscrito, preciosamente conservado na $\mathrm{Bi}$ blioteca da Ajuda com o título Da Fabrica Que faleçé ha Cidado de Lysboa.

Os sanvicentes chamavam-se assim, por terem no centro, entre duas estrêlas, São Vicente em pé, com a palma e um navio; os meios sanvicentes tinham também a palma e o navio, mas apenas o busto do santo. Tanto numa como noutra destas moedas, o fanático rei mandara gravar o título Zelator Fidei, que the fôra concedido pelo papa Paulo III - segundo Severim de Faria pelo grande zêlo e instâncias com que pediu o Tribunal do Santo Ofício da Inquisição para o seu reino.

As moedas de prata de D. João III foram o tostão, o meio tostão, o real ou vintém, o meio real ou meio vintém, o cinquinho, o real português ou dois vintens e o real português dobrado ou qua- 
tro vintens; as moedas de cobre foram os dez reais, os três reais, o real e o ceitil.

O tostão tinha a Cruz de Avís; o vintém tinha os dois $\mathbf{X X}$ indicativos do seu valor.

Oș dez reais, descritos por Francisco de Andrade eram também conhecidos por patacões e de pêso tão irregular, que um alvará de dezembro de 1551 , determinava que as moedas de cobre fôssem uniformes, pesando-se cada uma de per si.

\section{MOEDAS DE D. JOÃO HII}

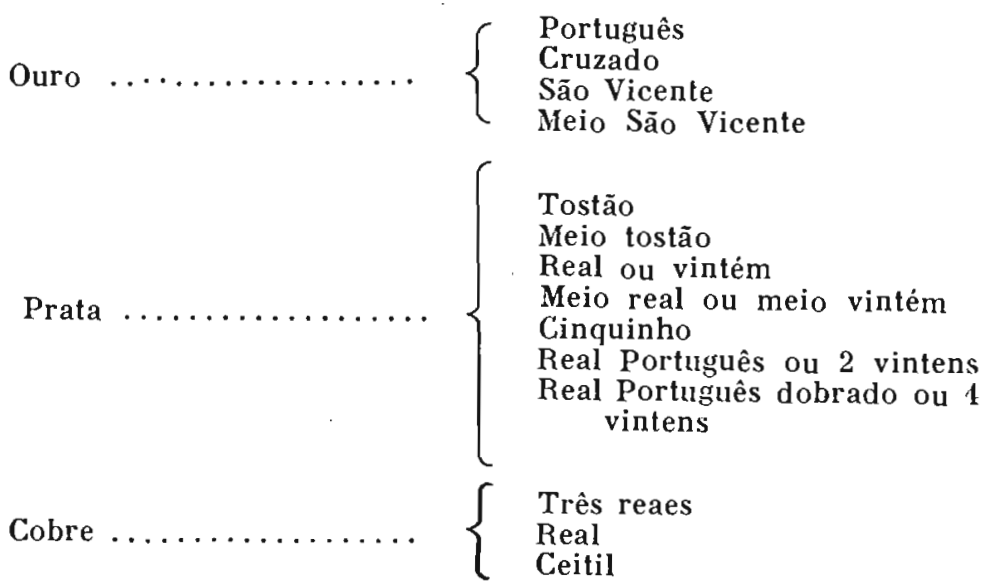

Moedas de ouro.

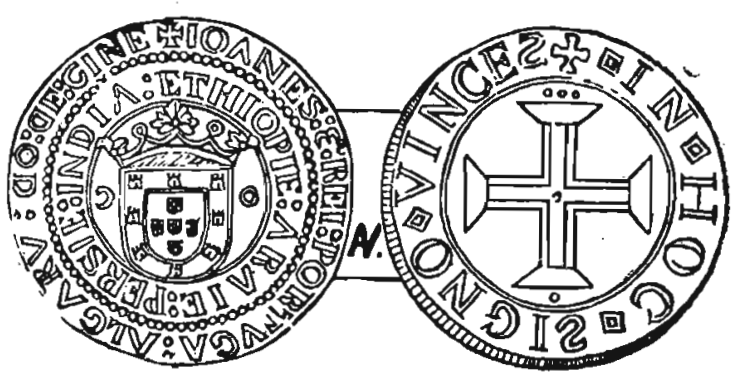

Fig. 44 - PORTUgues - Anverso: JoAnes 3. R. PORTUgalie. al. C. VL. IN A. D. G. C. ETI. ARABIA. PSI. e I. A legenda em dois círculcs, no centro o escudo das armas e a marca monetária $G O$.

Reverso: IN HOC SIGNO VINCES. Cruz da Ordem de Cristo. 


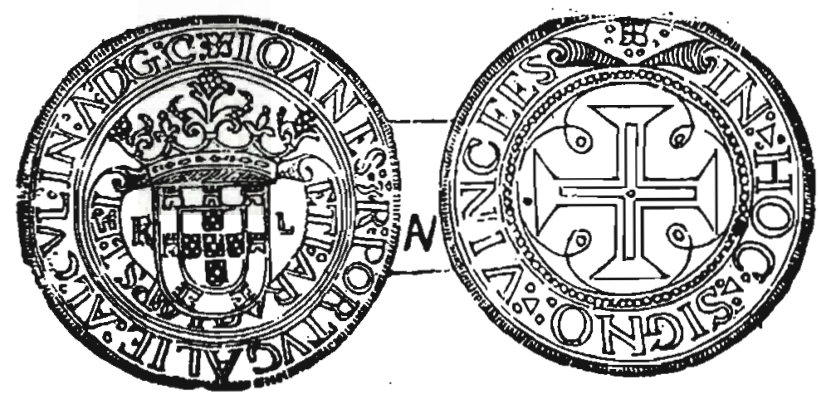

Fig. 45 - Outro exemplar, notando-se a Cruz da Ordem de Cristo com diferenteg ornatos. Marca monetária $R$ L.

Estas moedas valiam 4.000 réis.

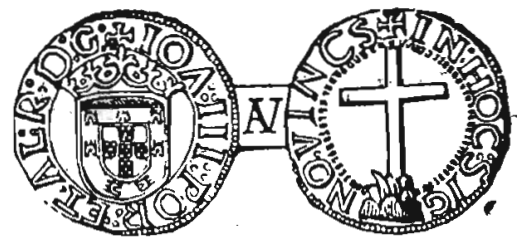

Fig. 46 - CRUZADO DE CRUZ DO MONTE CALVARIO - Anverso: JOA. III. PORT. ET A. R. D. G. Escudo das armas.

Reverso: IN HOC SIGNO VINCES. Cruz do Monte Calvário. Valia 400 réis.

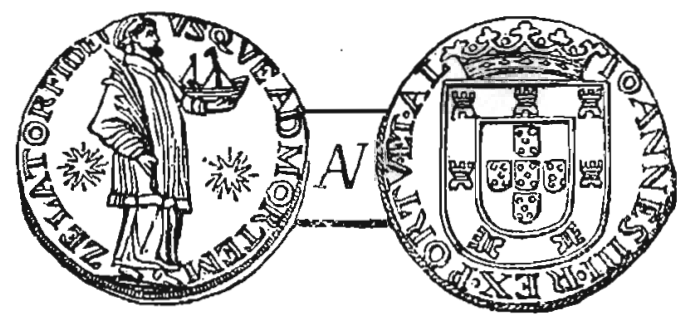

Fig. 47 - MOEDA DE S. VICENTE - Anverso: JOANNES III. REX PORT. ET AL. Escudo das armas.

Reverso: ZELATOR FIDEI USOUE AD MORTEM. Figura de São Vicente tendo um navio na mão esquerda e uma palma na direita.

Esta moeda foi lavrada quando se instituiu em Portugal o Tribunal da Inquisiçāo, pela Bula do Papa Paulo III.

Valia 1.000 réis. 
Moedas de prata.

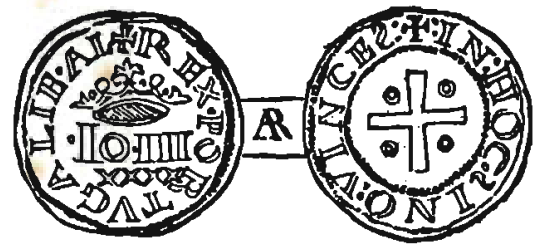

Fig. 48 - REAL PORTUGUes - Anverso: REX PORTUGAL ET ALG. D. G. Corôa e no campo da moeda: JO. III; por baixo XXXX.

Reverso: IN HOC SIGNO VINCES. Cruz de São Jorge

São Muito variados os tipos e legendas destas moedas. Valia 40 réis.

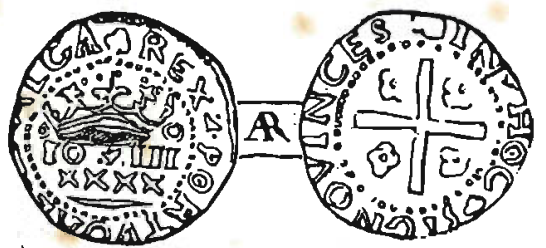

Fig. 49 - Outra variante do REAL PORTUGUES.

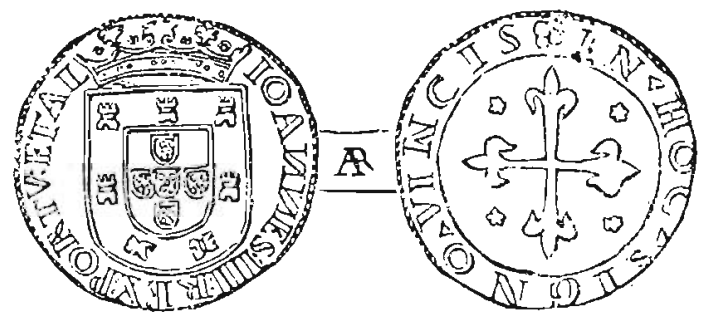

Fig. 50 - TOSTÃO - Anverso: JOANES. III. R. PORT. Escudo das armas. As moedas lavradas no Pôrto têm a marsa monetdária $P R$ ou $P$ e as de Lisboa não trazern marca

Reverso: IN HOC SIGNO VINCES. Cruz de Avís cantonada de quatro pontos.

Valia 100 réis. Estas moedas de prata trazendo a Cruz de Avís, de nova fabricação, foram lavradas de acôrdo com o Alvará de 26 de junho de 1555 . (Registro da Casa da Moeda, liv. 1, fls. 26) que ordenava "se fizessem duas fortes moedas de ouro de 1.000 réis e de 500 réis e de prata Tostóes, Meios Tastōes e Vintens". (Hist. Gen. Tom. IV, Tab. I, n. 61). 


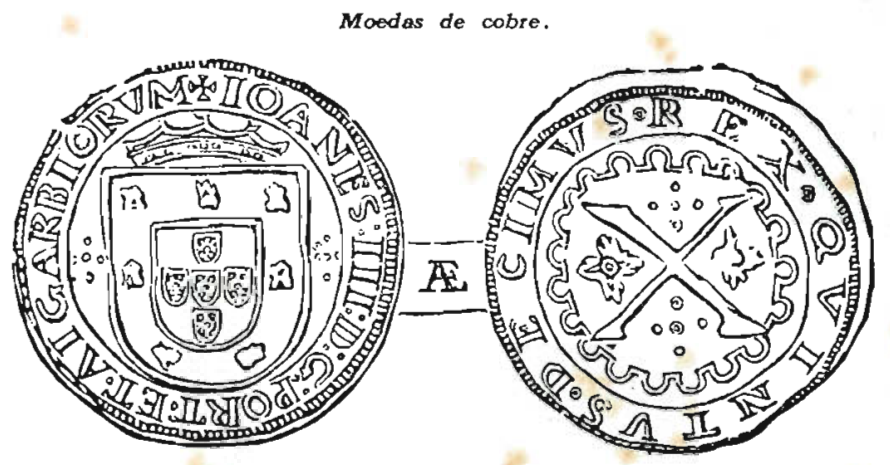

Fig. 51 - DEZ REIS - Anverso: JOANES. III. D. G. PORT. ALG. Escudo das armas.

Reverso: REX QUINTUS DECIMUS. No centro $\mathbf{X}$.

Valia 10 réis.

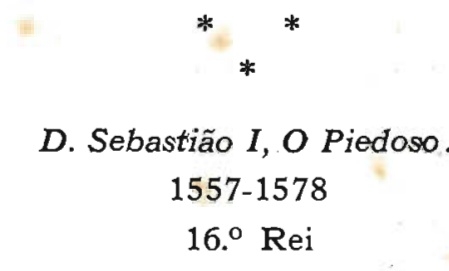

Histórico - D. SebastiãoI, filho do príncipe D. João e da princesa D. Joana, nasceu em Lisboa a 20 de janeiro de 1554.

Tinha três anos quando D. João III, seu avô, baixou ao túmulo; herdeiro do trono, durante sua menoridade governou o reino sua avó D. Catarina até ao ano de 1561 e depois seu tio, o cardeal D. Henrique, até 1567 , ano em que o moço rei assumiu os régios poderes.

Partindo para a Äfrica a 24 de junho de 1578, dali nunca mais voltou. Tinha 24 anos.

Desde tenra idade, D. Sebastião manifestara um caráter decididamente elevado e com substância para fazer dêle um rei que fôsse digno do trono português e ídolo dos seus vassalos; mas os jesuítas o afetaram desde os mais verdes anos de todos os preconceitos de uma educação ascética e o jovem soberano se deixou por êles arrastar até consumar a ruína da pátria. Os jesuítas aconselharam-no a partir para a f́ndia e coroar-se imperador do Oriente e antes da fatal expedição à África, incutiram no ânimo do infeliz monarca tais escrúpulos, a ponto de o estorvarem de casar-se para deixar o trono vago a um príncipe septuagenário, o cardeal D. Henrique. 


\section{$-266$}

Fatos notáveis dêste reinado - A glória adquirida em seu tempo pelos nobres capitães da sua côrte, aguilhoava a sua ambição de glória e tais eram os desejos que tinha de se tornar célebre, que era êle próprio que ia ao encôntro dos perigos e dos combates e foi sem dúvida essa ambição de glória que o levou a imaginar a conlquista de Marrocos e a humilhação do orgulho maometano. Foi a Tânger e a Ceuta em 1574, onde mostrou o seu valor e a sua coragem; mais tarde intentou sem reflexão e sem atender aos bons conselhos a desastrosa jornada da África em que perdeu a vida e comprometeu sem querer, a sua corôa e a sua pátria. Um exército heterogêneo e inexperiente, como êle, fascinou os seus belos desejos e tornou-se na sua mente, de pequeno que era, num exército invencivel, só porque se via rodeado da mais alta nobreza do país.

Partiu a 25 de janeiro de 1578 , deixanđo o govêrno do reino entregue a um̃a regência de cinco membros, por isso que o cardeal D. Henrique -0 recusara.

Chegando a Tânger deu batalha ao inimigo; travou-se a luta e o pequeno exército cristão composto de 16.500 homens, bate-se contra 150.000 ao mando de Moley-Moluk. Ós portuguêses lutain com heroismo desespêro, o campo alástrado de cadáveres. $\mathbf{D}$. Sebastião paga com a vida os seus erros, sabendo morrer como soldado valente ao lado dos seus bravos companheiros; os poucos que restaram foram feitos prisioneiros.

Esse desastre que a história registra como a batalha de $A l$ cácer-Kibir, feriu-se a 4 de agôsto de 1578. Três dias depois, encontraram um cadáver bàrbaramente mutilado e já meio decomposto, que os cavaleiros portuguêses disseram ser o corpo do infeliz monarca. Reclamado ao rei de Marrocos, êste o cedeu generosamente, regeitando o preço oferecido pelo cardeal-rei. Os restos mortais, que se supõem de $D$. Sebastião, foram então depositados na capela-mor do mcsteiro da Trindade, em Ceuta, onde se conservaram até Filipe II os mandar vir para o Algarve, no ano de 1582. Um século depois, D. Pedro II fêz colocar aquêles ossos num mausoléu construido na capela do lado da epistola na igreja de Belém, com o seguinte epitáfio:

"Conditur hoc tumulo, si vera est fama, Sebastus, Quem tulit in Libycis mors properata plagis;

Nec dicas falti qui vivere credit;

Pro lege extincto mors quasi vita fuit".

Neste reinado, entre outros varōes ilustres que tanto se distinguiram nas letras, teve lugar sobranceiro Luís de Camões, o imortal autor dos Lusiadas. 
Heráldica - Teve por emprêsa num campo, oito estrêlas, com o moto: Celsa serena favent.

Usou as mesmas armas de seu avô, a que juntou a corôa real e os castelos, um em chefe e três de cada lado.

Foi o primeiro rei que teve o tratamento de Majestade.

Numismática - As moedas de ouro de D. Sebastião foram o sanvicente, o meio sanvicente e os quinhentos reais. A esta moeda davam o nome de engenhoso, por ser fabricada por João Gonçalves que tinha aquela alcunha.

As primeiras moedas de prata lavradas em nome de D. Sebastião, ainda na gerência de D. Catarina, foram os tostões, os meios tostóes e os vintens; as de cobre continuaram a ser as mesmas do reinado anterior.

\section{MOEDAS DE D. SEBASTIAO}
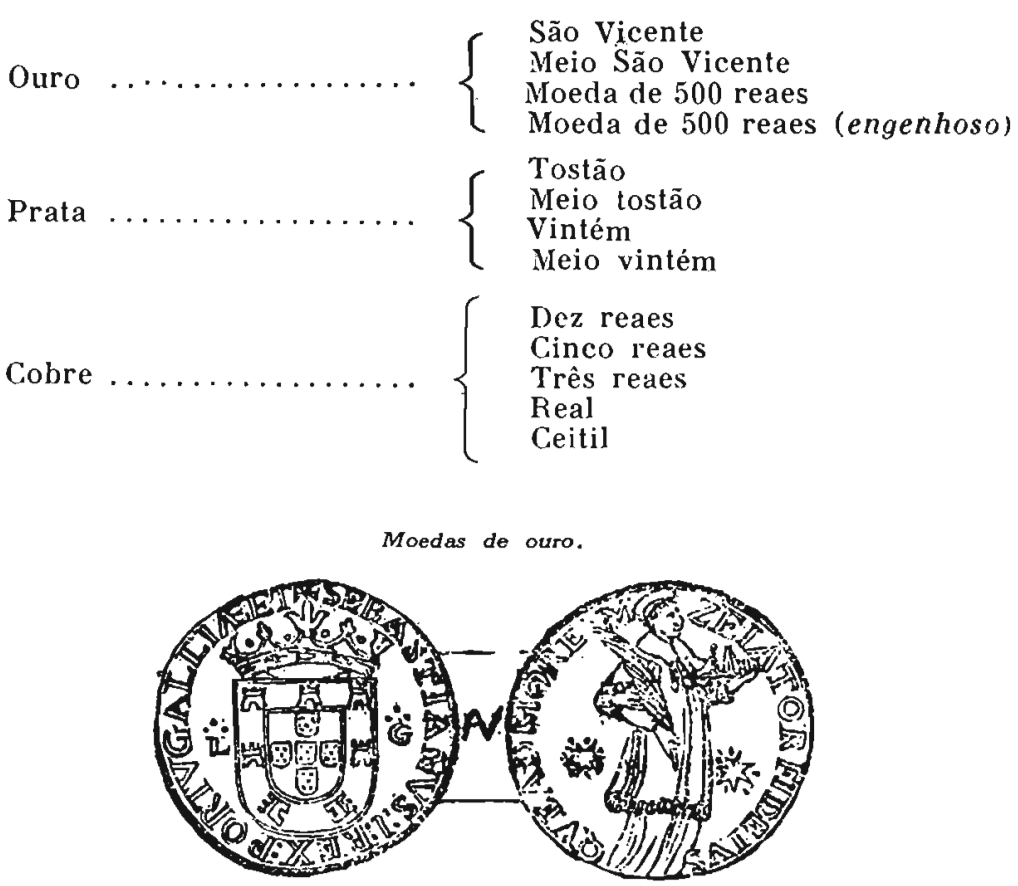

Fig. 52 - MOEDA DE S. VICENTE - Anverso: SEBASTIANUS I REX PORTUGALLIAE ET. Escudo das armas com coróa; aos lados as marcas moñárias $L G$.

Reverso: ZELATOR FIDEI USQUE AD MORTEM. Figura de São Vicente, com um navio na mäo esquerda e na direita uma palma.

Valia 1.000 réis. 


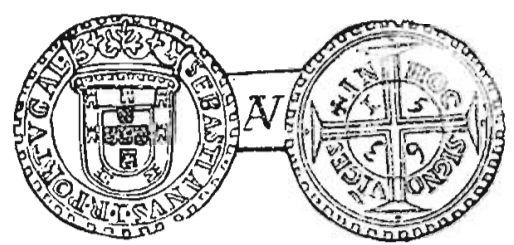

Fig. 53 - ENGENhoso - Anverso: Sebastianus. I. R. PORTUGal. Escudo das armas; algumas trazem a marca monetária aos lados do escudo - $G$ A - outras năo.

Reverso: IN HOC SIGNO VINCES. Cruz de Cristo cantonada com! os algarismos das datas entre dois círculos.

Valia 500 réis. Esta moeda Engenhaso "foi inventada e fundida por Joãu Gonçalves o Engenhoso, pondo-lhe uma orla para nāo poder ser cerceada. Todo o tipo e forma de letras é diverso das outras moedas contemparâneas, sendo esta a primeira moeda portuguêsa que se encontra com a data do ano em que foi lavrada. (Hist. Gen. Tom. IV, Tab. L, n. 79).

Moedas de prata.

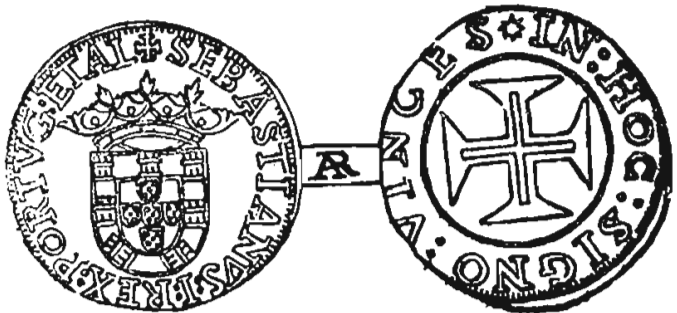

Fig. 54 - TOSTÃo - Anverso: SEBAstianUs. REX. PORT. ET. AL. Escudo das armas reaes com corôa aberta, apresentando-se outros exemplares com a corôa fechada. D. Sebastiāo foi o primeiro Rei de Portugal que usou a corôa real fechada, imitando os outros soberanos.

Reverso IN HOC SIGNO VINCES. Cruz da Ordem de Cristo; outros exemplares trazem a Cruz de Avís.

Algumas destas moedas costumam trazer as iniciais $\mathbf{P} \mathbf{R}$, mostrando terem sido lavradas no Pôrto.

Valia 100 réis.

Moedas de cobre.

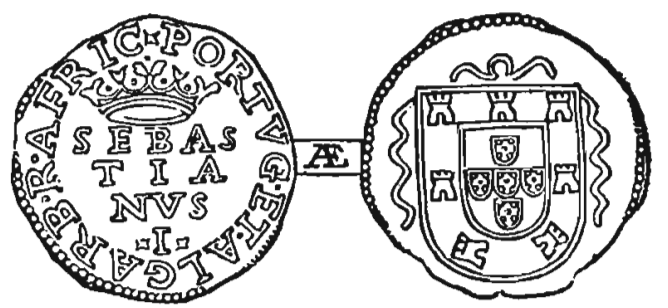

Fig. 55 - TRES REIS - Anverso: SEBASTIANUS, I. Por baixo da corôa e na orla: PORTUG. ET ALGARB. R. AFFRIC.

Reverso: Escudo das armas sem corôa e sem legenda. Valia três réis. 


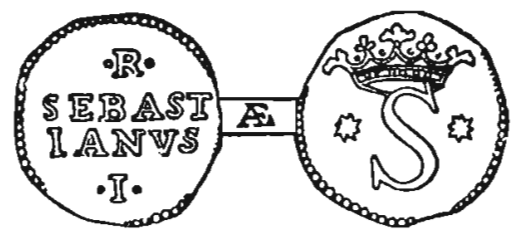

Fig. 56 - REAL DE COBRE - Anverso: A inicial 5 coroada e sem legenda, tendo aos lados duas pequenas estrêlas. Reverso: $R$. SEBASTIANUS I, no campo da moeda. Valia um real.

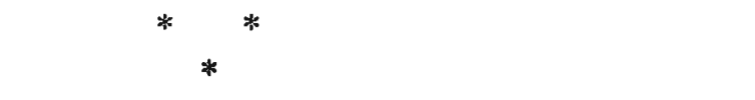

D. Henrique, $O$ Casto.

1578-1580

$17 .^{\circ} \mathrm{Rei}$

Histárico - $\mathrm{O}$ cardeal D. Henrique, oitavo filho do rei D. Manuel I, nasceu em Lisboa a 31 de janeiro de 1512 .

Foi aclamado a 28 de agôsto de 1578 .

Faleceu numa debilidade extrema, a 30 de janeiro de 1580, em Almeirim, com a idade de 68 anos, sendo seu corpo trasladado em 1582, para o túmulo ainda hoje existente na igreja de Belém.

D. Henrique foi príncipe humano, virtuoso e amante da justiça; cultivou as ciências e as letras; foi muito versado nas línguas grega, latina e hebraica, em teologia, filosofia e nas matemáticas, como discípulo do insigne matemático Pedro Nunes.

Todavia, deixou-se dominar pelos jesuítas, a quem era sobremaneira afeiçoado, chegando a aceitar o cargo de Inquisidor Geral, que exerceu com o maior rigor.

Subindo ao trono, de nenhuma de suas boas qualidades deixou reluzir o efeito, antes, pela sua tibieza e perplexidade, fêz cair a pátria sob o jugo estranho. Irresoluto, aflito e aterrado pelas ameaças de Filipe II de Castela, vacilou na escôlha de um sucessor, quando o tinha legítimo na duqueza de Bragança.

Cinco príncipes descendentes de D. Manuel se julgaram com direito à corôa e principiaram a alegar os seus direitos de sucessão: $10^{\circ}$ - Filipe II, de Espanha, filho da infanta D. Isabel; $2 .^{\circ}$ - Manuel Felisberto, duque de Sabóia, filho da infante D. Brites; $3 .^{\circ}$ - D. Antônio, prior do Crato, filho ilegítimo do infante D. Luís; $4 .^{\circ}$ - Rainúcio, príncipe de Parma, filho de D. Maria, filha do infante D. Duarte; $5 .^{\circ}$ - D. Catarina, filha de D. Duarte.

Além dos cinco, apareceu também como pretendente o papa Gregório XIII, fundando-se na razão de D. Henrique ser cardeal, 
considerando o reino como espólio vago à Santa Sé. Esta pretensão e a da rainha de França, Maria de Médicis, não tinham valor; aquela, por injustificável e esta porque não pudera provar a descendência que alegava, dizendo-se filha do rei Afonso III .

Não há dúvida que a candidatura de $D$. Catarina era a mais legal; filha de pais portuguêses, neta do rei D. Manuel I, casada com D. João, duque de Bragança, sustentado o seu direito pela Universidade de Coimbra, era portanto a que se julgava com sólido direito e assim o julgava também o próprio $D$. Henrique.

Nada, porém, o decidiu a tomar um arbítrio digno, político e decisivo; morreu deixando o reino à mercê dos ambiciosos, sem braços enérgicos e almas dedicadas que pudessem resistir à Espanha .

Muito bem o compreendeu o imortal cantor das glórias passadas, quando viu a nacionalidade ameaçada:

"Morro enfim com a pátria que tanto amei".

De fato, no dia 10 de junho de 1580 morria Luís de Camões e sete dias depois principiava o domínio castelhano que duraria sessenta anos.

Heráldica - O cardeal-rei teve por emprêsa um delfim envôlto numa âncora e como legenda: Festina lente.

Usou 'as armas do seu antecessor, conquanto já desde D. Fernando se encontrem escudos em ponta; foi, porém, neste reinaclo que mais apareceram.

Numismática - O cardeal D. Henrique mandou cunhar várias moedas semelhantes às de $\mathrm{D}$. Sebastião, em pêso, tipo e valor, diferindo apenas no nome do soberano.

Os governadores do reino, durante o interregno, cunharam também em ouro os quinhentos reais; em prata os tostões e meios tostöes.

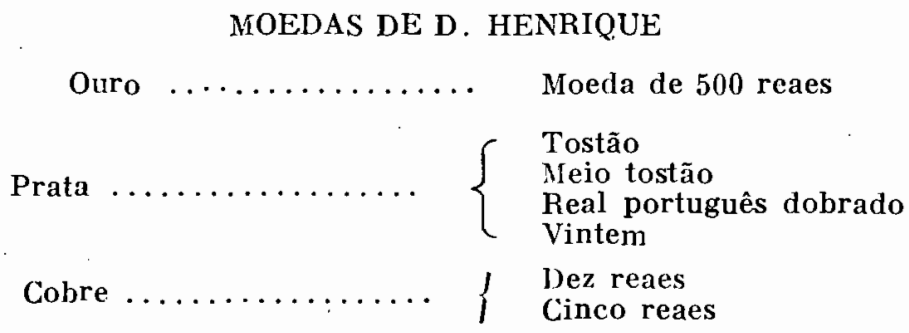




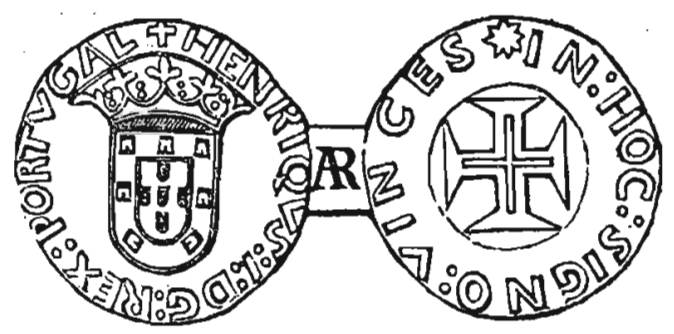

Fig. 57 - TOSTAO - Anverso: HENRIQUS. I. D. G. REX PORTUGAL. Escudo. das armas do reino.

Reverso: IN HOC SIGNO VINCES. Crux de Cristo.

Moedas de cobre.

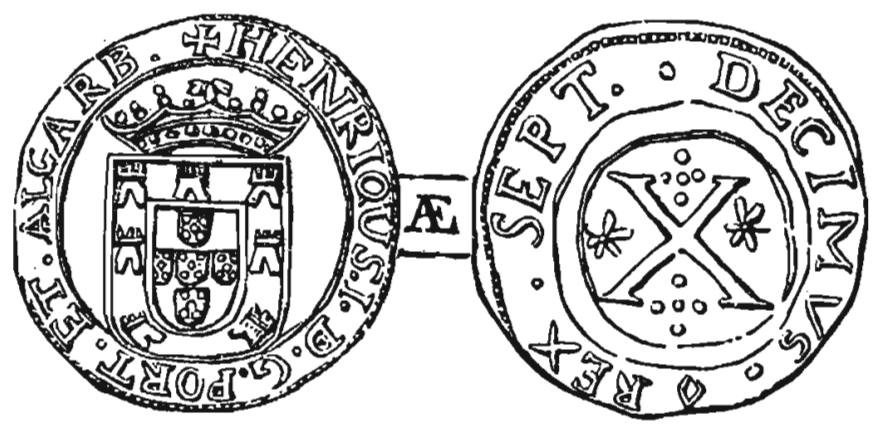

F:g. 58 - DEZ REIS - Anverso: HENRIQUS. I, D. G, PORT. ET. ALGARB. Eszudo das armas.

Reverso: REX. SEPT. DECIMUS, No centro $X$.

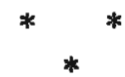

\section{INTERREGNO}

(31 de janeiro a 3 de dezembro de 1580)

Governadores do Reino de Portugal.

Histórico - Por morte do cardeal-rei D. Henrique ficou : governando o país uma regência de cinco membros, designados pelas côrtes constituídas em Lisboa: D. Jorge de Almeida, arcebijpo de Lisboa; Francisco de Sá e Menezes, camareiro-mor do falecido monarca; D. João de Mascarenhas, o defensor de Diu; Diogo Lopes de Souza, senhor de Miranda e João Teles de Menezes, senhor de Aveiras. 
Dos cinco governadores, três eram reconhecidamente favoráveis a Castela. Nesse estado foi-se pervertendo o brio nacional; nem ousavam entregar o reino aos espanhóis, receando a indignação do povo, nem organizavam a nação para repelir a invasão que em Espanha se preparava contra Portugal.

Enquanto os governadores estavam em Setúbal, o povo em Santarém aclamava D. Antônio, Prior do Crato, filho natural do infante $D$. Luís, o qual entra em Lisboa a 24 de junho de 1580 , elevado ao título de rei de Portugal; começa a exercer os seus poderes e obrigações de soberano, governando e mandando cunhar moeda, ao mesmo tempo que se prepara para a resistência.

A êsse tempo, o duque de Alba, atravessando a fronteira à frente de um grande exército, fazia as mais importantes praças do Alentejo prestarem obediência a Filipe II.

D. Antônio organiza tumultuàriamente um pequeno exército de oito mil homens, com os quais tentou tomar o passo ao invasor. Mas em breve viu os seus soldados e grande parte da nobreza abandonarem a sua causa e a da nação, para irem a Badajós prestar vassalagem a Filipe.

A regência, de Setúbal, transfere-se para São Lucas, onde aclama D. Filipe II de Castela, primeiro em Portugal, por alvará de 7 de agôsto, proclamado em Badajós.

Em virtude dos acontecimentos que se sucederam, o duque de Alba invadiu Lisboa, acampando além da ponte de Alcântara com vinte mil homens de seu exército. Aí é atacado pelo Prior do Crato, com a diminuta fôrça de quatro mil homens mal armados e o resultado foi desastroso. O Prior, vendo-se perdido, embarca para a França e daí para as ilhas dos Açores, que reconheciam a sua autoridade.

D. Filipe, entrando em Portugal, decretou que os deputados se reunissem em Tomar, onde resolvera celebrar côrtes e a 17 de julho de 1580, Filipe II de Espanha, era declarado rei heriditário de Portugal, com o título de Filipe I.

MOEDAS MANDADAS LAVRAR PELOS GOVERNADORES DO REINO

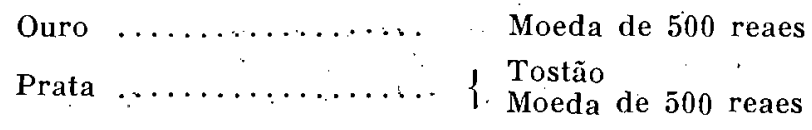




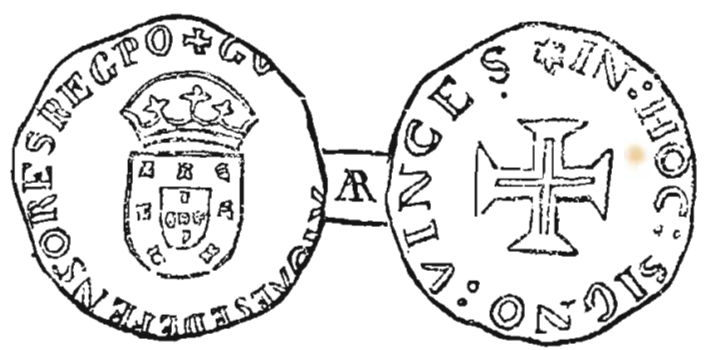

Fig. 59 - TOSTAO - Anverso: GUBERNATORES E DEFENSORES REG. P. Escudo das armas com corôa fechada.

Reverso: IN HOC SIGNO VINCES. Cruz de Cristo.

\section{Antônio, O Prior do Crato.}

(No reino de 19 de junho a 25 de agôsto de 1580 e na ilha Terceira de 5 de agôsto do mesmo ano a 3 de agôsto de 1583).

Histórico - Concluída a luta no continente, estava ainda reservada uma parte importante à ilha Terceira e ao seu benemérito corregedor, Cipriano de Figueiredo e Vasconcelos. O Prior do Crato havia sido aclamado em Angra, a 5 de agôsto de 1580 e para obrigar a ilha a reconhecer o senhorio de Castela, foi desembarcar na Salga, D. Pedro Valdez, à frente de uma divisão que os terceirenses derrotaram.

Catarina de Médicis ainda enviou ao arquipélago dos Açores, que como já dissemos seguia o partido de $D$. Antônio, uma esquadra comandada pelo conde de Brissac, que aportou a São Miguel, mas que foi desbaratada pelo marquês de Santa Cruz que tinha o comando da esquadra espanhola (1582).

Em 1589, Isabel da Inglaterra, socorre com doze mil homens a D. Antônio, que chegou ainda ao Tejo; foi, porém, mal recebid.’, por terem chegado ao conhecimento dos portuguêses a concessão desonrosa que fizera dos domínios de Portugal, retirando-se o Prior do Crato para Paris, onde morreu pobre, com o título de rei (1595).

D. Antônio havia recebido uma instrução acima do vulgar, era de meia estatura, presença agradável, intrépido mas imprudente, de gênio volúvel, desconfiado e pouco composto em costumes.

Numismática - D. Antônio não pôde, pelos poucos dias que ali se demorou, cunhar moeda em Setúbal, como Barbosa Machado 
pretendia; cunhou-a depois em Angra, durante os três anos de sua resistência a Filipe II.

Foi Manuel da Silva quem primeiro em Angra tratou de organizar Casa da Moeda no pátio do hospital

“com juízes, escrivão e peritos, sendo o abridor dos cunhos o mestre Gaspar Ribeiro, ouvires muito hábil”.

Aí se fabricaram moedas de ouro de quinhentos reais e em prata cruzados, tostões e meios tostôes.

Além destas, D. Antônio teve em cobre os quatro reaes, os dois reaes, o real e o ceitil.

Por ocasião de gravíssimas dificuldades financeiras, muitas das moedas de D. Antônio foram carimbadas com um açor, ficando a valer o dôbro, desde que tivessem essa contramarca.

MOEDAS DE D, ANTONIO

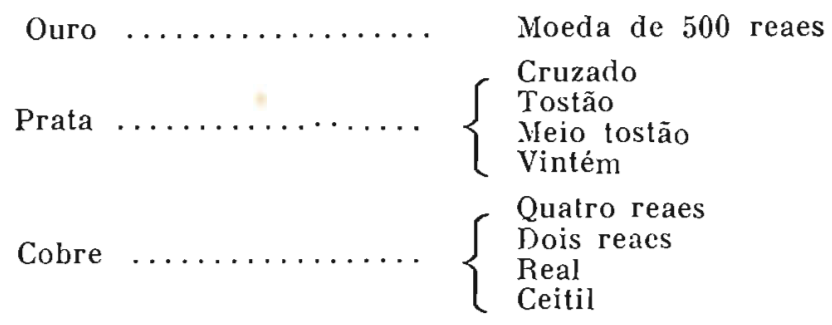

Moedas de prata.

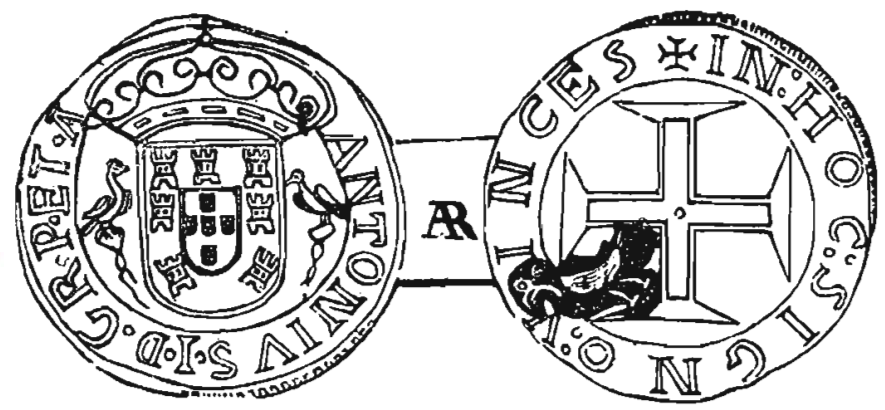

Fig. 60 - CRUzado - Anverso: ANTONIUS. I. D. G. R. ET. AL. Escudo das armas com um Açor de cada lado.

Reverso: IN. HOC. SIGNO. VINCES. Cruz da Ordem de Cristo e a contramarca do Açor para lhe aumentar o valor. 


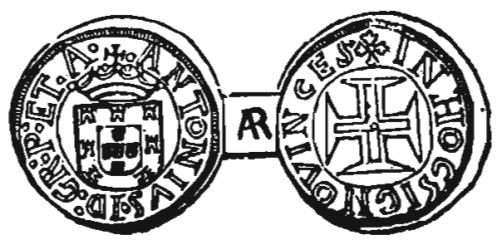

Fig. 61 - MEIO TOSTÃO - Anverso: ANTONIUS. I. D. G. R. P. ET A. Escudo das armas.

Reverso: IN. HOC. SIGNO. VINCES. Cruz da Ordem de Cristo.

(Continua no próximo número).

ALVARO DA VEIGA COIMBRA

da Sociedade Numismática Brasileira. 